\title{
PENGEMBANGAN MEDIA PEMBELAJARAN SEJARAH LOKAL BERBASIS AUDIO VISUAL CORAK KAIN SASIRANGAN DI SMAN 5 BANJARMASIN
}

\author{
Oleh: Fitri Mardiani \\ SMAN 2 Banjarmasin \\ Email: Fitri.mardiani28@gmail.com
}

\begin{abstract}
ABSTARCT
Local history includes a wide range of knowledge and noble values in a society that can be used as one perspective that is held in life. Those values can be attributed to learning course that leads to the affective attitude of the students. For society, the fabric sasirangan open just an ordinary cloth but the terms of the meaning and significance of the sublime. In this study local history lesson on the meaning attributed to shades of fabric sasirangan. The method used in this research is descriptive evaluative namely by combining the results of field exposure and testing of the products with evaluative methods. Stages in the development of this research are: 1) The preliminary research stage, 2) stage of media development, 3) stages try uj media (product). For data analysis hit feasibility media has been developed using a Likert scale ranges 5. The media effectiveness test using the test $\mathrm{T}$. From the $\mathrm{T}$ test results we can conclude that $\mathrm{H} 0$ is rejected. Then there are differences in effect on student achievement scores between the experimental class and control class. Through these results we can conclude that the use of instructional media berbasi sasirangan fabric patterns can impact the value of student achievement. As for the assessment of cultural awareness, It can be said there has been a good improvement of student achievement scores between before being given to the media after being given media.
\end{abstract}

Keywords: Media development, Patern of Sasirangan, Cultural Awareness

\section{PENDAHULUAN}

Pendidikan adalah usaha sadar dan sistematis yang dilakukan oleh orang-orang yang diserahi tanggung jawab untuk mempengaruhi peserta didik agar mempunyai sifat dan tabiat sesuai dengan cita-cita pendidikan (Ahmad Munib, 2004:34). Menurut Nuroni Suryomukti (2013:29), pendidikan merupakan proses tiada akhir yang di upayakan oleh siapapun, terutama (sebagai tanggungjawab) negara. Sedangkan menurut Hamalik (2007:73) pendidikan merupakan suatu proses sosial, karena berfungsi memasyarakatkan anak didik melalui proses sosialisasi di dalam masyarakat tertentu. Pendidikan merupakan sebuah upaya untuk meningkatkan kesadaran dan ilmu pengetahuan, pendidikan telah ada seiring dengan lahirnya peradaban manusia.
Pendidikan dewasa ini lebih berorientasi kepada pendidikan formal yang sering dilakukan di sekolah. Pendidikan dapat dikatakan berhasil apabila peranan guru sebagai tenaga pendidik profesional dapat melaksanakan pendidikan secara efektif yang dilakukan dengan langka-langkah yang tepat seperti manajemen pendidikan yang baik, suasana belajar dikelas yang aktif serta pemberian umpan balik dan penguatan untuk peningkatan kualitas diri siswa melalui penerapan kurikulum, pengembangan metode mengajar yang relevan dan memanfaatkan media yang terus berkembang seperti media IT. Belajar merupakan pengembangan pengetahuan, keterampilan, atau sikap yang baru ketika seseorang berinteraksi dengan informasi 
dan lingkungannya. Belajar yang efektif dapat dilakukan dengan memanfaat teknologi dan media yang ada. Proses belajar mengajar seringkali dihadapkan pada berbagai macam kendala, tak terkecuali pada pembelajaran sejarah. Terdapat beberapa materi yang sering kali bagi siswa dianggap sebagai sesuatu yang membosankan

Pembelajaran sejarah sering diidentikkan dengan mengafal tanggal, tahun, tempat, tokoh, dan rentetan peristiwa masa lalu. Menurut Kartodirdjo (1992) dalam (Abd. Rahman Hamid, 2014: 49), ada dua manfaat yang dapat diperoleh peserta didik dari hasil belajar sejarah yakni, 1) Dari masa dan situasi sekarang kita dapat mengeksplorasikan fakta-fakta atau kekuatan - kekuatan yang berperan di masa lalu. Maka dengan belajar sejarah, banyak dari situasi sekarang dapat diterangkan (sebab-akibat), 2) dengan menganalisis situasi masa kini kita dapat membuat proyeksi ke masa depan.

Pembelajaran sejarah di sekolah, sebagian besar hanya mengajarkan tentang kisah tanpa makna, dan belum memberikan kesinambungan dengan keadaan di sekitar lingkungan tempat mereka tinggal. Kebanyakan pendidik masih menggunakan pembelajaran konvensional yang bersifat verbalistis atau lebih dikenal dengan metode tradisional yakni ceramah. Gaya belajar pembelajaran sejarah yang monoton dalam penyampaian suatu peristiwa disajikan secara konvensional ini tentunya kurang efektif dan menarik bagi siswa. Peran guru sebagai seorang fasilitator dituntut mampu melaksanakan pembelajaran yang efektif dan juga menyenangkan. Permendiknas No. 16 Tahun 2007 menyatakan bahwa guru harus memiliki kemampuan menggunakan media pembelajaran dan sumber belajar yang relevan dengan karakteristik peserta didik dan mata pelajaran yang diampu untuk mencapai tujuan pembelajaran secara utuh.
Pada masa kini, khususnya bagi guru sejarah perlu mempunyai kemampuan untuk menciptakan suasana belajar yang kondusif, aktif dan menyenangkan bagi siswa-siswanya. Di era informatika, visualisasi berkembang dalam bentuk gambar bergerak (animasi) yang dapat ditambahkan suara (audio). Pemanfaatan teknologi merupakan kebutuhan mutlak dalam dunia pendidikan. Tidak dapat dipungkiri bahwa teknologi multimedia mampu memberikan kesan yang besar terhadap bidang media pembelajaran. Multimedia telah mengembangkan proses pengajaran dan pembelajaran ke arah yang lebih dinamis. Teknologi multimedia mampu memberikan kesan besar dalam bidang media pembelajaran.

Video pembelajaran merupakan suatu media yang cukup efektif untuk membantu proses pembelajaran, baik pembelajaran masal atau pembelajaran individual. Video merupakan media yang fleksibel dan dapat diatur sesuai dengan kebutuhan. Selain itu, video juga dapat menambah dimensi baru terhadap pembelajaran karena siswa dapat merasakan seperti berada di suatu tempat yang sama seperti yang tengah di putar dalam video. unsur-unsur yang terdapat dalam media video adalah gambar bergerak dan suara. Kedua unsur ini oleh penonton (siswa) disadari atau tidak telah membuat mereka menikmati sajian yang terdiri dari informasi berbentuk gambar bergerak (movie image) dan suara (audio). Dalam tayangan video pembelajaran, unsur gambar merupakan unsur utama dan unsur suara sebagai pelengkap. Hal ini berarti bahwa gambar merupakan perhatian utama indra penglihatan siswa, dan suara sebagai penguat dan penjelas gambar yang sulit divisualisasikan. Melalui media pembelajaran, komunikasi yang berlangsung dalam kegiatan belajar mengajar tidak selalu monoton hanya guru dan siswa saja. 
Sejarah merupakan ilmu pengetahuan yang menelaah tentang asal usul dan perkembangan serta peranan masyarakat di masa lampau berdasarkan metodologi tertentu. Terkait dengan itu, pengetahuan mengenai masa lampau biasanya selalu terkandung nilai-nilai kearifan yang dapat digunakan untuk melatih kecerdasan, membentuk sikap, watak dan kepribadian peserta didik.

Mata pelajaran sejarah telah diberikan pada tingkat pendidikan dasar sebagai bagian integral dari mata pelajaran IPS, sedangkan pada tingkat pendidikan menengah diberikan sebagai mata pelajaran sendiri. Dalam pengajarannya, baik pada pendidikan dasar, menengah, atas, atau perguruan tinggi pembelajaran sejarah memiliki fungsi-fungsi tertentu. Berdasarkan Permendiknas no. 22 tahun 2006, mata pelajaran sejarah bertujuan agar peserta didik memiliki kemampuan berupa (1) membangun kesadaran peserta didik tentang pentingnya waktu dan tempat yang merupakan sebuah proses dari masa lampau, masa kini, dan masa depan. 2) melatih daya kritis peserta didik untuk memahami fakta sejarah secara benar dengan didasarkan pada pendekatan ilmiah dan metodologi keilmuan. 3) menumbuhkan apresiasi dan penghargaan peserta didik terhadap peninggalan sejarah sebagai bukti peradaban bangsa Indonesia di masa lampau. 4) menumbuhkan pemahaman peserta didik terhadap proses terbentuknya bangsa Indonesia melalui sejarah yang panjang dan masih berproses hingga masa kini dan masa yang akan datang. 6) menumbuhkan kesadaran dalam diri peserta didik sebagai bagian dari bangsa Indonesia yang memiliki rasa bangga dan cinta tanah air yang dapat diimplementasikan dalam berbagai bidang kehidupan baik nasional maupun internasional. Oleh karena itu, fungsi pengajaran sejarah sangat penting bagi siswa.
Peran media pembelajaran dalam kegiatan belajar mengajar merupakan proses komunikasi dan berlangsung dalam suatu sistem, maka media pembelajaran menempati posisi yang cukup penting sebagai salah satu komponen sistem pembelajaran. Tanpa media, komunikasi tidak akan terjadi dan proses pembelajaran sebagai proses komunikasi juga tidak akan bisa berlangsung secara optimal. Penggunaan media pembelajaran memiliki beberapa kelebihan, yaitu: 1) efisiensi pembelajaran karena siswa dapat menghayati secara langsung visual lewat alat peraga yang digunakan, 2) meningkatkan motivasi belajar, 3) memberi kesempatan dalam melakukan inovasi dalam memperdayakan media pembelajaran.

Kini nilai-nilai kearifan lokal mulai di angkat kembali, sebab dalam kebudayaan lokal mengandung adat istiadat, kebiasaan dan tradisi yang memiliki makna mendasar dalam kehidupan. Nilai-nilai lokal tersebut bahkan menjadi suatu kekuatan dan mampu menjadi perekat dalam masyarakat. Kearifan lokal sebagai sebuah simbol, dan sebagai sebuah kebijaksanaan yang bersumber dari tata nilai dan budaya di suatu tempat. Jika di pelajari pada dasarnya mengandung nilai per kehidupan dan memiliki makna yang mendalam. Menurut Turmono Rahardjo, dkk. (2013) Masyarakat memiliki sikap hidup yang etis dan taat terhadap adat istiadat warisan nenek moyang serta selalu mengutamakan kepentingan-dalam kepentingan umum atau masyarakat dibandingkan dengan kepentingan pribadi. Menurut Victor (2009:2),

"Cultural apperception also includes knowing the narratives and dominant themes of a society. What are these themes and why are they important, Instilled in all societies are basic themes which capture the basic value systems of a people". 
Nilai-nilai kearifan lokal yang terkandung dalam sejarah mencakup nilai pedagogis, nilai praktis, nilai teoritis, nilai ke Tuhan-an, dan nilai filsafat. Nilai-nilai kearifan banyak tersimpan dalam tradisi lokal. Nilai budaya di suatu daerah dianggap sebagai sesuatu yang luhur oleh masyarakat pendukungnya sehingga cenderung untuk diwariskan dari generasi ke generasi. Nilai tersebut berintikan adat istiadat serta mempunyai fungsi kultur dan fungsi sosial yang memberi penuntun dan dihormati oleh masyarakat setempat yang meyakininya.

Budaya menjadi dasar bagi setiap masyarakat untuk berpikir, bersikap, dan berperilaku. Kebudayaan secara lebih luas, merupakan salah satu karakteristik anggota masyarakat termasuk di dalamnya peralatan, pengetahuan, dan cara berpikir dan bertindak yang telah terpolakan yang dipelajari dan disebarkan serta bukan merupakan hasil pewarisan biologis (Mahmud, 2011: 43). Selain menjadi dasar hidup bagi suatu masyarakat, budaya juga menjadi identitas diri bagi setiap masyarakat yang menghidupnya (Turmono Rahardjo, dkk. 2013: 63). Sedangkan menurut Ting-Toomey (2005) menyebutkan bahwa salah satu dari fungsi budaya adalah sebagai identity Meaning Function.

Menurut Alexon (2001: 1) ada dua hal penting yang berkenaan dengan tantangan dan permasalahan yang dihadapi dunia pendidikan di Indonesia saat ini. Pertama, tantangan yang dihadapi lembaga pendidikan formal yang mempunyai peran penting dalam membangun suatu masyarakat Indonesia baru di era globalisasi dan reformasi. Kedua, sistem pendidikan yang cenderung parsial telah menjadikan manusia-manusia Indonesia yang kurang memahami dan menghargai budaya. Adapun pendidikan budaya yang semestinya ada dalam konteks pendidikan di Indonesia yakni pendidikan nilai, yaitu tentang nilai-nilai yang bersumber dari budaya bangsa Indonesia sendiri dalam rangka membina kepribadian generasi muda.

Nilai-nilai budaya yang ada memang harus dilestarikan dan dijaga sebagai suatu jati diri dan identitas sebagai sebuah bagian dari masyarakat. Karena jika tidak, maka nilai-nilai tersebut akan hilang, tergerus oleh arus globalisasi yang kian hari kian deras menyapu kehidupan generasi di era ini.

Berdasarkan hal tersebut, dalam setiap kearifan lokal yang ada di daerah mengandung nilai-nilai kebajikan dalam kehidupan berbangsa dan bernegara. Dikhawatirkan apabila nilai-nilai kearifan budaya lokal tersebut tidak dijaga secara perlahan akan hilang. Dengan demikian, salah satu lembaga yang juga ikut bertanggung jawab untuk melestarikan nilai-nilai budaya lokal tersebut adalah melalui pendidikan. Kearifan lokal sebagai cerminan budaya masyarakat dapat digali melalui cerita rakyat, seni tradisi, dan adat istiadat yang berkembang dalam suatu masyarakat. Salah satu yang menarik adalah seni yang tergambar pada kain asli dari Kalimantan Selatan yakni kain sasirangan. Kain sasirangan merupakan sebuah seni budaya yang dimiliki oleh masyarakat Banjar, kain ini merupakan kain yang sakral dan menjadi bagian dari sejarah masyarakat Banjar di masa Lambung Mangkurat.

Terdapat banyak makna dan nilainilai kehidupan yang dapat diimplementasikan ke dalam pembelajaran sejarah. Pembelajaran sejarah dengan memanfaatkan media visualisasi dalam bentuk foto-foto dan video mengenai kain sasirangan, di dalamnya memuat bagaimana kehidupan awal manusia Indonesia dalam menata kehidupan baik secara individu maupun dalam hubungan bersosial serta kaitan nya dengan kehidupan masyarakat Banjar dalam memaknai budaya melalui corak-corak kain sasirangan. Penggunaan kain sasirangan ini 
dipilih karena para peserta didik yang pada umumnya berasal dari Banjarmasin sendiri, tidak memahami kandungan nilai yang terdapat dalam corak-corak kain sasirangan, padahal nilai-nilai tersebut. Bertolak dari problematik ini, peneliti ingin memberikan informasi, pengenalan, dan pemaknaan terhadap para peserta didik mengenai banyaknya makna dan nilai yang dapat dipetik dari corak-corak yang terdapat dikain tersebut. Oleh sebab itu untuk memberikan pembelajaran sejarah yang inovatif dan kontekstual guru di harapkan mampu menyediakan mediamedia yang kreatif dalam menarik perhatian dan minat siswa dalam menciptakan suasana belajar yang menyenangkan.
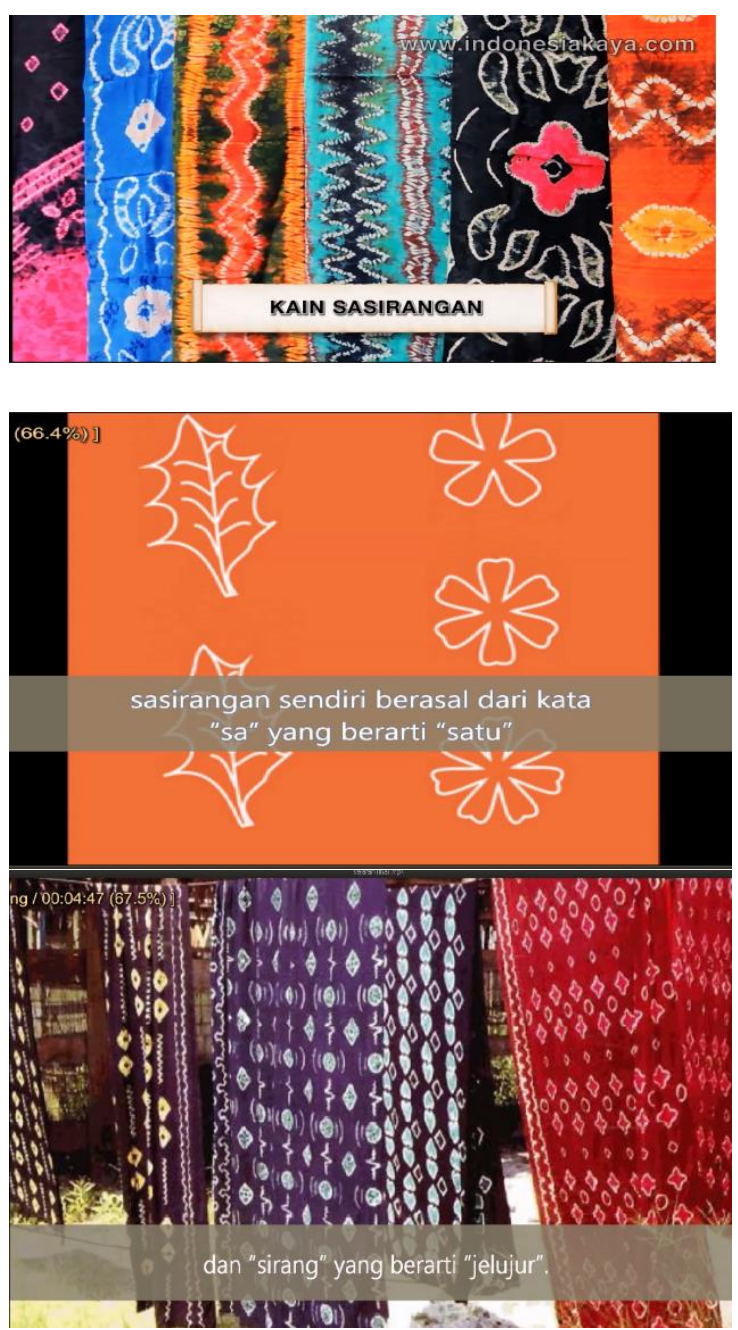

\section{Gambar 1. Cuplikan Video yang dikembangkan}

Berdasarkan hal tersebut, fokus penelitian ini adalah untuk menyempurnakan pembelajaran yang selama ini berlangsung yaitu dengan mengembangkan Video Pembelajaran Sejarah Lokal Berbasis Corak Kain Sasirangan Untuk Meningkatkan Kesadaran Budaya. Berdasarkan hal tersebut, maka tujuan dari penelitian dan pengembangan media ini yaitu:

1. Untuk memperoleh gambaran tentang penggunaan media pembelajaran pada mata pelajaran sejarah di SMAN 5 Banjarmasin.

2. Untuk memperoleh mendeskripsi prosedur pengembangan video pada pembelajaran sejarah lokal berbasis corak kain sasirangan dapat meningkatkan kesadaran budaya siswa SMAN 5 Banjarmasin.

3. Untuk Menganalisis implementasi video pembelajaran sejarah lokal berbasis corak kain sasirangan dapat meningkatkan kesadaran budaya siswa SMAN 5 Banjarmasin.

4. Untuk menganalisis sejauh mana Keefektifan pembelajaran sejarah dengan menggunakan video pembelajaran berbasis corak kain sasirangan dapat meningkatkan kesadaran budaya siswa SMAN 5 Banjarmasin.

\section{METODE PENELITIAN}

Penelitian ini bertempat di SMAN 5

Kota Banjarmasin. Penelitian pengembangan merupakan suatu langkah yang dilakukan untuk menyempurnakan atau mengembangkan suatu produk dan menguji keefektifannya secara longitudinal atau bertahap. Dalam penelitian ini peneliti mencoba untuk mengembangkan media pembelajaran sejarah. Penelitian dan pengembangan pendidikan adalah proses 
yang digunakan untuk mengembangkan dan memvalidasi produk penelitian.

Produk tidak hanya mencakup obyek material, seperti buku pelajaran, film pendidikan, dan sebagainya (Borg \& Gall, 1983:772). Menurut Richey \& Nelson dalam Sumargono, (2014:82), bahwa jenis penelitian pengembangan adalah penelitian yang berorientasi pada pengembangan suatu produk yang proses pengembangannya dideskripsikan secara teliti dan produk yang diperoleh dievaluasi. Produk yang dihasilkan dalam penelitian dan pengembangan adalah berupa video pembelajaran yang berisi slide dari gambargambar dari berbagai motif dan corak kain sasirangan. Dikemas semenarik mungkin dengan visualisasi gambar bergerak dan efek suara yang mendukung sehingga menghasilkan seperti layaknya movie clip.

Metode yang digunakan di dalam penelitian ini adalah deskriptif evaluatif yakni dengan menggabungkan hasil pemaparan di lapangan dan pengujian produk dengan metode evaluatif. Produk yang dikehendaki dalam penelitian ini adalah sebuah media pada pokok pembahasan Tradisi Sejarah Masyarakat Indonesia masa Pra Sejarah yang dikemas dalam Video Compact Diks berbasis corak kain sasirangan untuk meningkatkan kesadaran budaya siswa. Pendekatan penelitian dan pengembangan dirasa tepat karena tujuannya adalah mengembangkan media pembelajaran yang efektif sesuai kondisi dan kebutuhan nyata di sekolah. Penelitian ini dimaksudkan untuk menghasilkan media pembelajaran sejarah yang kreatif, aktif, dan inovatif yakni media video pembelajaran sejarah lokal berbasis corak kain sasirangan.

Tahap-tahap dalam penelitian pengembangan ini yaitu: 1) Tahap penelitian pendahuluan, 2) tahap pengembangan media, 3) tahap uji coba media (produk). Untuk analisis data mengena kelayakan media yang telah di kembangkan menggunakan skala Likert rentang 5. Adapun uji efektivitas media menggunakan uji $T$. Pada tahap studi pendahuluan melalui studi literatur (kajian pustaka dan penelitian terdahulu). Selain itu peneliti juga melakukan survei lapangan di SMAN 5 Banjarmasin untuk mengetahui penggunaan media pembelajaran sejarah yang sedang berlangsung. Pendekatan ini menggunakan pendekatan kualitatif deskriptif yakni menguraikan teori dan juga materi atau kompetensi yang akan diajarkan.

Tahap pengembangan sebagai penggabungan tahap perencanaan dan pengembangan dari produk yang mengandung kegiatan-kegiatan penentu tujuan, menentukan pihak-pihak yang terlibat, pengembangan, merumuskan bentuk partisipasi pihak terlibat, menentukan prosedur kerja dan uji kelayakan. Hasil dari kegiatan ini menciptakan media pembelajaran yang siap untuk di uji cobakan. Tahap uji coba di lapangan terdiri dari uji coba kelompok kecil dan uji coba kelompok besar. Di samping itu juga adanya tahap revisi terhadap hasil uji coba media pembelajaran. Hasilnya kemudian didapatkan draft desain media yang siap di uji kelayakannya.

Uji coba media atau produk dilakukan setelah rancangan produk selesai. Uji coba media atau produk bertujuan untuk mengetahui apakah produk tersebut layak dan efektif untuk digunakan. Uji coba media atau produk juga melihat sejauh mana pencapaian yang telah diraih apakah sudah tepat sasaran atau belum memenuhi sasaran yang ditujukan. Media atau produk yang baik memenuhi dua kriteria yaitu: kriteria pembelajaran (instructinal criteria) dan kriteria penampilan (presentation criteria). Sebelum dilakukan uji coba di lapangan hendaknya dilakukan uji coba ahli baru setelah itu dilakukan uji coba pada kelompok kecil dan uji coba kelompok besar. Uji efektiftas media menggunakan metode kuantitatif untuk melihat sejauh 
mana pengaruh media tersebut secara signifikan ataupun sebaliknya.

Selanjutnya, sebelum melakukan pengukuran terhadap siswa, maka terlebih dahulu dilakukan uji validitas dan uji reliabilitas instrumen yang akan digunakan. Baik itu instrumen soal maupun instrumen angket. Untuk uji validitas dan reliabilitas soal tes, digunakan software analisis butir soal Iteman 4.3. Sedangkan untuk uji validitas dan reliabilitas angket menggunakan softwafe SPSS 19. Berikut ini hasil dari pengujian validitas dan Reliabilitas instrumen soal dan angket:

1. Validitas dan Reliabilitas Soal Tes

\begin{tabular}{|c|c|c|c|c|c|}
\hline $\begin{array}{c}\text { Jm } \\
\text { lh } \\
\text { So } \\
\text { al }\end{array}$ & P & Rpbis & $\begin{array}{c}\text { Reli } \\
\text { abeli } \\
\text { tas }\end{array}$ & $\begin{array}{c}\text { Item } \\
\text { gugu } \\
\text { r }\end{array}$ & $\begin{array}{c}\text { Item } \\
\text { dipa } \\
\text { kai }\end{array}$ \\
\hline & - & & & & \\
& 0,3 & - & & & \\
25 & 67 & $0,001-$ & 0,80 & 5 & 20 \\
& - & 0,695 & 7 & & \\
& 0,6 & & & & \\
\hline
\end{tabular}

2. Validitas dan Reliabilitas Angket

\begin{tabular}{|c|c|c|c|c|}
\hline $\begin{array}{c}\text { Jml } \\
\mathrm{h} \\
\text { Soal }\end{array}$ & $\begin{array}{c}\text { Validit } \\
\text { as }\end{array}$ & $\begin{array}{c}\text { Reliab } \\
\text { elitas }\end{array}$ & $\begin{array}{c}\text { Item } \\
\text { gugu } \\
\mathrm{r}\end{array}$ & $\begin{array}{c}\text { Item } \\
\text { dipak } \\
\text { ai }\end{array}$ \\
\hline 35 & $\begin{array}{c}0,674- \\
-0,076\end{array}$ & 0,791 & 10 & 25 \\
\hline
\end{tabular}

\section{HASIL PENELITIAN DAN PEMBAHASAN}

Dari hasil observasi di lapangan, guru hanya memberikan pembelajaran sebatas yang ada di LKS dan buku panduan belajar, tidak mengaitkan pada pembelajaran sejarah lokal yang perlu diketahui siswa terutama untuk memberikan pemahaman bagi siswa terhadap budaya asli dari masyarakat Banjar dan pemaknaan yang terkandung dalam setiap corak kain sasirangan sangat berguna bagi kehidupan. Dalam gaya belajar guru mengandalkan model belajar konvensional seperti ceramah dan diselingi dengan diskusi antara guru dan siswa atau juga antar siswa. Guru hanya memberikan fakta-fakta dan konsep-konsep saja, sehingga memberikan dampak pada gaya belajar siswa yang hanya bisa memaparkan fakta-fakta hafalan namun mereka tidak bisa menjelaskan hal-hal yang mereka tahu dengan kehidupan mereka sehari-hari.

Perihal pembelajaran sejarah di SMAN 5 Banjarmasin tepatnya pada kelas $\mathrm{X}$, baik guru dan siswa tentang media pembelajaran sejarah yang digunakan selama ini ada beberapa masalah antara lain : (1) Siswa tidak mengetahui secara detail kebudayaan tradisi masyarakat banjar yang berkaitan dengan pemaknaan pada corak kain sasirangan (2) Adanya kesenjangan antara tujuan pelajaran sejarah dan materi yang disampaikan terhadap siswa mengenai kebudayaan lokal. Guru tidak pernah memberikan materi kebudayaan lokal sehingga siswa tidak mengenal kebudayaan tersebut menyebabkan melemahnya sikap kesadaran budaya lokal yang dimiliki siswa, (3) Hasil wawancara kepada siswa menunjukkan bahwa siswa mendukung dan menantikan secara antusias bila dalam materi pelajaran Sejarah diajarkan mengenai kebudayaan lokal, (4) Guru sejarah di SMAN 5 Banjarmasin dalam memberikan materi sejarah hanya menggunakan media verbal tanpa sekalipun menggunakan media audio visual. Padahal siswa mengharapkan adanya media pembelajaran sejarah yang inovatif untuk menghindari kebosanan dalam mengikuti pelajaran sejarah.

Selama ini guru mata pelajaran sejarah di SMAN 5 Banjarmasin dalam kegiatan pembelajaran hanya menggunakan media visual berupa Microsoft Powerpoint. Guru mata pelajaran sejarah belum mampu untuk mengembangkan sebuah media berupa 
audio visual dalam bentuk video dikarenakan beberapa kendala yang ada yaitu ketersediaan waktu dan ketidak pahamanan guru untuk mengembangkan sebuah media. Hal iniah yang membuat guru tidak dapat membuat sebuah media pembelajaran audio visual (video) tersebut. Dari kegiatan pendahuluan diperoleh gambaran sebagai berikut:

a. Penggunaan media pembelajaran berupa audio visual oleh guru kurang

b. Ada keinginan oleh guru untuk mengembangkan media pembelajaran berbasis audio visual dalam bentuk video

Dari hasil temuan di atas dapat disimpulkan bahwa SMAN 5 Banjarmasin memang sudah memanfaatkan media pembelajaran dan menggunakan fasilitas yang ada disekolah, namun dalam proses pembelajaran guru tidak hanya menggunakan buku teks tetapi juga menggunakan media pembelajaran yang menarik dalam bentuk visual. Muncul keinginan dari guru agar adanya peningkatan kualitas dalam pembelajaran serta minat belajar yang tinggi melalui sebuah media pembelajaran yang dapat merangsang dan memotivasi siswa.

Setelah tahap produksi media selesai dilakukan tahap selanjutnya adalah melakukan uji coba terhadap produk (media) yang telah dihasilkan melalui beberapa tahapan uji coba yakni uji coba terhadap ahli materi dan ahli media pembelajaran. Kemudian dilanjutkan dengan tahap uji coba untuk mengetahui kelayakan media pembelajaran menggunakan audio visual berupa video pembelajaran yang dikembangkan dalam penelitian ini. Hasil dari valdasi ahli materi diperoleh nilai rata-rata yaitu, 4,1. Sedangkan Hasil dari valdasi ahli media diperoleh nilai rata-rata yaitu, 3,5. Nilai tersebut dalam skala Likert berarti Cukup Baik. Berdasarkan validasi ahli materi terhadap media video pembelajaran sejarah lokal berbasis corak kain sasirangan, maka perbaikan yang dilakukan yaitu Pendalaman materi di jabarkan lebih jelas, urutan tampilan disesuaikan dengan materi ajar. Sedangkan dari ahli media, perbaikan yang mesti dilakukan yaitu Resolusi Gambar yang ditampilkan dalam video kualitasnya masih rendah serta jeda waktu perpindahannya terlalu cepat.

Kemudian dilanjutkan dengan tahap uji coba untuk mengetahui kelayakan media pembelajaran menggunakan audio visual berupa video pembelajaran yang dikembangkan dalam penelitian ini. Uji coba dilakukan kepada siswa dengan tiga tahapan yakni uji coba satu-satu, uji coba kelompok kecil, dan uji coba lapangan. Hasil dari uji coba satu-satu diperoleh nilai rata-rata yaitu, 3,7. Nilai tersebut dalam skala Likert berarti Cukup Baik. Selanjutnya, hasil dari uji coba kelompok kecil diperoleh nilai rata-rata yaitu, 3,8. Nilai tersebut dalam skala Likert berarti Cukup Baik. Sedangkan hasil dari uji coba lapangan diperoleh nilai rata-rata yaitu, 3,9. Nilai tersebut dalam skala Likert berarti Baik. Melalui serangkaian uji coba ahli dan uji coba terhadap peserta didik akhirnya produk final media pembelajaran menggunakan audio visual berupa video pembelajaran dihasilkan dengan memasukkan sasaran atau komentar atau tanggapan dan revisi dari ahli materi, ahli media pembelajaran, serta siswa.

Setelah revisi dilaksanakan sesuai dengan masukan-masukan ahli materi dan ahli media serta uji coba, maka tahap selanjutnya yaitu implementasi media dalam pembelajaran. Hasil dari pengimplementasian media di dapati peningkatan hasil belajar dan peningkatan kesadaran budaya. Dari hasil uji $\mathrm{T}$ dapat disimpulkan bahwa H0 ditolak. Hal ini diketahui dari nilai sig 0,000 sehingga kurang dari 0,05. Maka terdapat perbedaan pengaruh terhadap nilai prestasi siswa antara kelas eksperimen dan kelas kontrol. Melalui hasil tersebut dapat disimpulkan bahwa dengan penggunaan media 
pembelajaran berbasi corak kain sasirangan dapat memberikan pengaruh terhadap nilai prestasi siswa.

Adapun untuk penilaian kesadaran budaya, dari hasil uj $\mathrm{T}$ maka dapat disimpulkan bahwa $\mathrm{HO}$ ditolak. Hal ini diketahui dari nilai sig $0,000<0,05$. Maka dapat dikatakan telah terdapat peningkatan yang baik dari nilai prestasi siswa antara sebelum diberi media dengan setelah diberi media.

\section{KESIMPULAN}

Berdasarkan hasil penelitian dan pembahasan, maka dapat diambi kesimpulan:

Guru hanya memberikan pembelajaran sebatas yang da di LKS dan buku panduan belajar, tidak mengaitkan pada pembelajaran sejarah lokal yang perlu diketahui siswa terutama untuk memberikan pemahaman bagi siswa terhadap budaya asli dari masyarakat Banjar dan pemaknaan yang terkandung dalam setiap corak kain sasirangan sangat berguna bagi kehidupan. Sedangkan dari siswa tidak mengetahui secara detail kebudayaan tradisi masyarakat banjar yang berkaitan dengan pemaknaan pada corak kain sasirangan. Dan siswa mendukung dan menantikan secara antusias bila dalam materi pelajaran Sejarah diajarkan mengenai kebudayaan lokal.

Setelah tahap produksi media selesai dilakukan tahap selanjutnya adalah melakukan uji coba terhadap produk (media) yang telah dihasilkan melalui beberapa tahapan uji coba yakni uji coba terhadap ahli materi dan ahli media pembelajaran. Hasil dari validasi ahli materi diperoleh nilai rata-rata yaitu, 4,1 (Baik). Sedangkan Hasil dari validasi ahli media diperoleh nilai rata-rata yaitu, 3,5. (Cukup Baik). Kemudian dilanjutkan dengan tahap uji coba untuk mengetahui kelayakan media pembelajaran menggunakan audio visual berupa video pembelajaran yang dikembangkan dalam penelitian ini. Uji coba dilakukan kepada siswa dengan tiga tahapan yakni uji coba satu-satu, uji coba kelompok kecil, dan uji coba lapangan. Hasil dari uji coba satu-satu diperoleh nilai rata-rata yaitu, 3,7. (Cukup Baik). Selanjutnya, hasil dari uji coba kelompok kecil diperoleh nilai rata-rata yaitu, 3,8. (Cukup Baik). Sedangkan hasil dari uji coba lapangan diperoleh nilai ratarata yaitu, 3,9. berarti (Baik).

Dari hasil uji T dapat disimpulkan bahwa H0 ditolak. Maka terdapat perbedaan pengaruh terhadap nilai prestasi siswa antara kelas eksperimen dan kelas kontrol. Melalui hasil tersebut dapat disimpulkan bahwa dengan penggunaan media pembelajaran berbasi corak kain sasirangan dapat memberikan pengaruh terhadap nilai prestasi siswa. Adapun untuk penilaian kesadaran budaya, dari hasil uj T maka dapat disimpulkan bahwa $\mathrm{H} 0$ ditolak. Dapat dikatakan telah terdapat peningkatan yang baik dari nilai prestasi siswa antara sebelum diberi media dengan setelah diberi media.

\section{DAFTAR PUSTAKA}

Alexon. 2010. Pembelajaran Terpadu Berbasis Budaya. Bengkulu: UNIB Press.

Borg, WR. \&M.D. Gall. 1983. Educational Reseach: An Introduction, Fourth Edition. New York: Longman.

Hamalik, Oemar. 2007. Metode Belajar dan Kesalahan Belajar. Bandung: Tarsito

Hamid, Abd. Rahman. 2014. Pembelajaran Sejarah. Yogyakarta: Ombak.

Mahmud dan Ija Sunata. 2014. Antropologi Pendidikan. Bandung: Pustaka Setia.

Sumargono. 2014. Pengembangan Media Pembelajaran Sejarah Nasional Berbasis Macro Media Flash Untuk Meningkatkan Nasionalisme pada siswa Kelas XII IPS SMA Surakarta. UNS: Tesis. 
Suryomukti, Nuroni. 2013. Teori-Teori Pendidikan: Tradisional, (Neo) Liberal, Marxis-Sosialis,

Postmodern. Yogyakarta: ArRuzzmedia.

Victor. M, Rosello. 2009. Culture Awarenes or Culture Aperception is They a Difference. Small wars Journal. 